\title{
Introgression or low molecular differentiation? The case of Carabus maacki
}

\section{DIETRICH MOSSAKOWSKI}

Institute for Ecology \& Evolutionary Biology University of Bremen

Seeweg 10, D-23942 Gross Schwansee, Germany dmossa@uni-bremen.de

Key words: introgression, Carabus clatratus, Carabus maacki, Carabus porrecticollis
Received January 14, 2016.

Revised July 19, 2016.

Accepted September 20, 2016

\begin{abstract}
Background: Carabus (Limnocarabus) maacki aquatilis and C. (Euleptocarabus) porrecticollis of the Japanese Island Honshu reveal a remarkably low sequence difference in the mitochondrial ND5 gene, similar to that existing between the subspecies of $\mathrm{C}$. porrecticollis although the morphology is quite different. On the other hand C. maacki aquatilis from Japan is quite distinct to European C. clatratus in ND5 sequences and that was the reason to established $\mathrm{C}$. maacki as a separate species, formerly a subspecies of $\mathrm{C}$. clatratus. My hypothesis is that data on these taxa are better interpreted by assuming that $\mathrm{C}$. maacki is in fact a $\mathrm{C}$. clatratus but suffered in its Japanese form aquatilis an introgression from C. porrecticollis.
\end{abstract}

Material and Methods: Twenty-one specimens were sequenced and seven sequences were retrieved from GenBank. They comprise C. porrecticollis and C. maacki aquatilis form Japan, C. maacki maacki from the Asian mainland, and C. clatratus from Far East and Europe. The data were analysed using the maximum likelihood method and were presented as a tree and as visualisation of sequences differences.

Results: The hypothesis that $\mathrm{C}$. maacki is a C. clatratus but suffered an introgression by C. porrecticollis is supported by the results because (i) C. maacki maacki from Russian Primorje clustered with Far East and European C. clatratus in mitochondrial ND5 sequences, and (ii) Japanese C. maacki aquatilis clustered with $\mathrm{C}$. clatratus in the nuclear gene data of wingless, but both differ in the same way to C. porrecticollis.

Conclusions: The presented data corroborate the hypothesis of an introgression from $\mathrm{C}$. porrecticollis to the population of $\mathrm{C}$. maacki aquatilis on Honshu, Japan. The taxon maacki cannot maintain species status. Its two subspecies should be considered as subspecies of C. clatratus (C. clatratus maacki from the Asian mainland, C. clatratus aquatilis from Japan).

\section{INTRODUCTION}

In their study on Carabus porrecticollis, Kim et al. (1) used sequences 1 of the mitochondrial gene ND5 as a molecular marker for populations all over its distribution area on Honshu, Japan. Taking the Japanese $C$. maacki aquatilis as an outgroup, the authors obtained the surprising result that $C$. maacki aquatilis differed from $C$. porrecticollis only in the same extent as the $C$. porrecticollis subspecies do among themselves: the maximum divergence in ND5 sequences between the three lineages of C. porrecticollis was $3.1 \%$, identical to the difference between C. porrecticollis and C. maacki aquatilis. They suggested a split of C. porrecticollis into several species instead of subspecies (1, p. 444). 


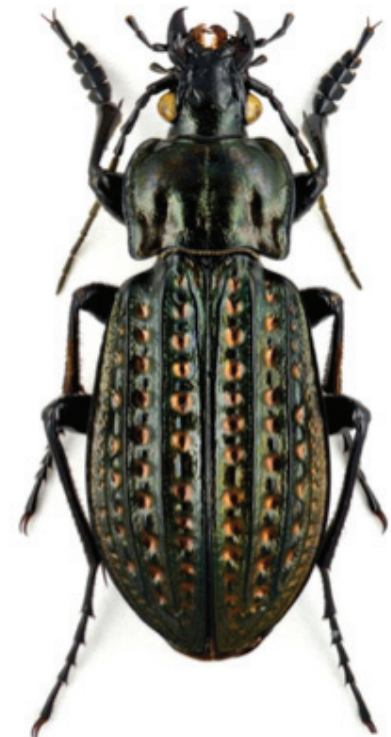

clatratus C. Europe
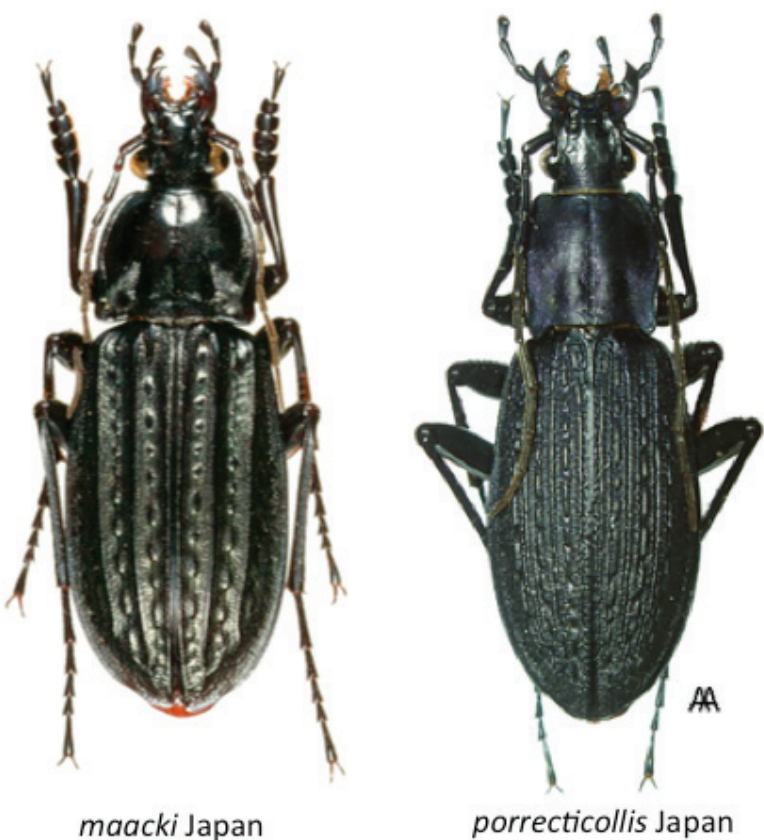

Figure 1 Habitus of male Carabus (Limnocarabus) clatratus ${ }^{1}$ and C. maacki aquatilis ${ }^{2}$ and C. (Euleptocarabus) porrecticollis ${ }^{3}$. By courtesy of O. Bleich ${ }^{1}$ (26); Y. Katsuro ${ }^{2}$ (in 27), and A. Anitchenko ${ }^{3}$ (27)

This interpretation will be questioned in the present paper, because hybridisation between species is known very well in Carabus from nature and laboratory experiments (e.g. 2, 3). Even Jeannel (4) described a new species that turned out to be a hybrid. Molecular markers in various Carabus species and subgenera documented evolution of separate taxa by introgressive hybridisation: e.g. Chrysocarabus solieri (5), Ohomopterus (6, 7, 8, 9, 10), Chrysocarabus splendens - rutilans $(11,12)$, Chrysocarabus splendens - punctatoauratus (13), Leptocarabus (14) and Mesocarabus (15).

The C. clatratus from the Russian province of Primorje was described as subspecies $C$. maacki Morawitz, 1862 and the Japanese form as $C$. aquatilis Bates, 1883. Imura et al. (16) ranked C. maacki as a separate species, based on the large differences between $C$. clatratus from Europe and C. maacki aquatilis from Japan (Kimura-2-Parameter (17) of $5.4-5.3 \%$ (18); threshold values of K2P are usually greater than 3 between closely related species). Deuve $(19,20)$ followed this interpretation and promoted $C$. maacki from subspecies to species. This is the status in 'The Carabus of Japan' (21) (Imura \& Mizusawa 2013), as well as in Schütze \& Kleinfeld (22).

On the other hand, Löbl \& Smetana (23) and Lorenz (24) placed C. maacki as a subspecies of $C$. clatratus. Osawa et al. (25) did not use the name maacki; their Limnocarabus of Japan was ranked as a subspecies and named C. clatratus aquatilis. For practical reasons, I use the classification of Imura et al. (16) (species status of C. maacki with $C$. maacki aquatilis and the nominate form $C$. maacki maacki as subspecies) in order to use unambiguous allocation of names.

Only a few species exist within the genus Carabus that occur over a wide range in the Palaearctic region, one of which is Carabus (Limnocarabus) clatratus L. with a distribution area ranging from Ireland to the Far East. Carabus (Euleptocarabus) porrecticollis is endemic to the Japanese island Honshu. The subgenera Limnocarabus and Euleptocarabus comprise a monophyletic clade without doubt $(1,16)$, based on morphological characters (i.e. elytra sculpture, spine at the internal sac) and molecular data. Carabus maacki is morphologically closer to C. clatratus than to C. porrecticollis: e.g. in the shape of the body, the structure of the elytra (Fig. 1) and in characters of the endophallus, the spine of which is long in C. clatratus and C. maacki but short in C. porrecticollis (Fig. 2). (See also 16, 25, and 28).

\section{Hypothesis}

An introgression event will be tested as an alternative hypothesis.

The high molecular similarity of $C$. maacki aquatilis and $C$. porrecticollis exists because $C$. maacki suffered an introgression from $C$. porrecticollis in former times. The large difference between $C$. clatratus and C. maacki aquatilis is a result of this introgression event. In consequence, C. maacki should be downgraded to the rank of subspecies.

Because the C. maacki data are only from Japanese specimens and only from a mitochondrial gene (which is 


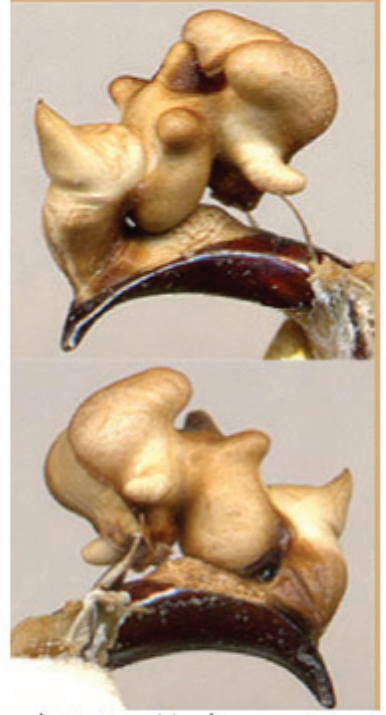

clatratus Ural

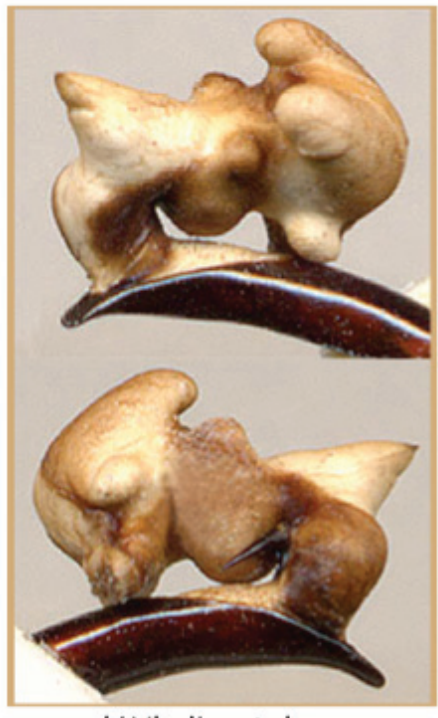

maacki Vladivostok

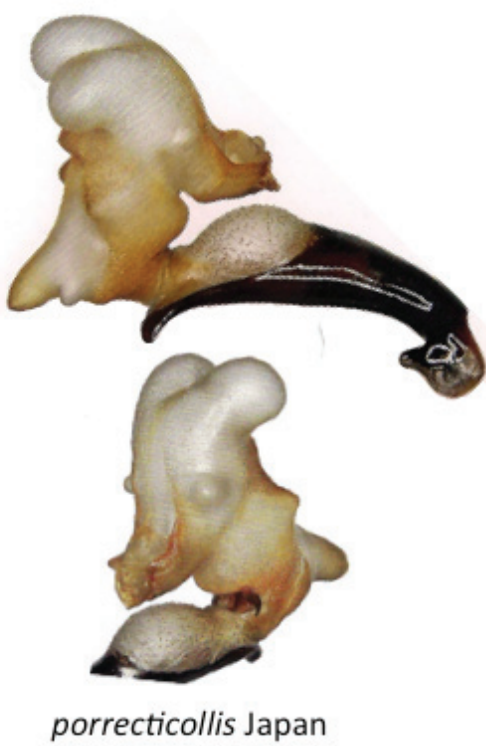

porrecticollis Japan

Figure 2 Aedeagus with inflated internal sac of C. clatratus ${ }^{1}$, C. maacki maacki ${ }^{1}$, and C. porrecticollis ${ }^{2}$. By courtesy of O. Berlov (28) and Y. Imura \& K. Mizusawa ${ }^{2}$ (21).

only propagated maternally), three comparisons can generate this result:

- Specimens from the Asian mainland (C. maacki maacki) have a different pattern of the ND5 sequence than the Japanese ones (C. maacki aquatilis).

- The ND5 differences between both C. clatratus and C. maacki maacki from the Asian mainland compared to C. porrecticollis are similar, but much greater than those between $C$. porrecticollis and $C$. maacki aquatilis from Japan.

- Nuclear sequence data will display minor differences between $C$. clatratus and $C$. maacki from Japan, as well as from the Asian mainland but greater to $C$. porrecticollis.

\section{MATERIAL AND METHODS}

The specimens used for the analyses are listed in Table 1. They include $C$. porrecticollis, $C$. maacki from Japan $(C$. m. aquatilis) and the Asian mainland (C.m. maacki), and C. clatratus from Europe and Far East (Jakutsk).

\section{Molecular methods}

The NADH-Dehydrogenase subunit 5, including a part of tRNA ${ }_{\text {Phe }}$ (ND5; $1083 \mathrm{bp}$ ), was analysed as a mitochondrial gene. The primer-pair His and Phe for ND5 (29) was used to perform PCR and sequencing. In some cases, intermediate primers were used for ND5 (e.g. 270 and 270r, 850 and 850r) (30). As a nuclear gene, we analysed the protein coding wingless (wg, $440 \mathrm{bp}$ ) using the primers CARWL-1 und CARWL-2 (6). Most sequences used here were generated by Michael A. Miller (www. kmbioservices.de).

Sequences were aligned with CLUSTALX (31), distances calculated using MEGA6 (32) and phylogenetic analyses were performed using the Maximum Likelihood Method (DNAML in PHYLIP 3.6) (33) using speedier but rougher analysis, empirical base frequencies, a transition/transversion ratio of 2.0, global rearrangements, and bootstrap procedure with 1000 pseudo-replicates. Additionally, a visualisation is given of sequence differences position per position.

\section{RESULTS}

The mitochondrial ND5 and the nuclear wingless gene of twenty-one specimens were sequenced. The suitable data included sixteen new ND5 sequences and ten of wingless. In addition, seven sequences were revealed from GenBank, four of ND5 and three of the wingless gene (Tab. 1). An additional four wingless sequences from other locations were excluded because they differed only in singletons.

\section{Mitochondrial gene}

\section{Distances ND5}

The Japanese $C$. maacki aquatilis exhibited minor differences in comparison to C. porrecticollis and major differences in comparison to $C$. clatratus but also high values in comparison to C. maacki maacki from the Asian mainland (Primorje) (Table 2). On the other hand, C. maacki maacki from the Asian mainland was very similar to $C$. clatratus (framed numbers in Tab. 2). Such low distances were also found within the $C$. maacki aquatilis taxon. 
Table 1 List of Carabus specimens used for this study.

\begin{tabular}{|c|c|c|c|c|c|c|c|}
\hline $\begin{array}{l}\text { Carabus } \\
\text { species }\end{array}$ & Sub-species & $\begin{array}{l}\text { Sample } \\
\#\end{array}$ & & Location & $\begin{array}{l}\text { Collector/ } \\
\text { Donator }\end{array}$ & $\begin{array}{l}\text { Collect. } \\
\text { date }\end{array}$ & GenBank \# \\
\hline porrecticollis & kansaiensis & 196 & JP Osaka & Mt. Kongo & T. Sota & 2010 & KX377443 \\
\hline porrecticollis & kansaiensis & 196 & JP Osaka & Mt. Kongo & T. Sota & 2010 & KX380583 \\
\hline porrecticollis & kansaiensis & S19 & JP Shiga & Yogo & T. Sota & 2010 & KX380579 \\
\hline porrecticollis & porrecticollis & & JP Nagano & Matsumoto & (34) Sota \& Ishikawa & & AY183585 \\
\hline maacki & aquatilis & 195 & JP Aomori & Tsugaru & Y. Okuzaki/T. Sota & 2010 & KX377447 \\
\hline maacki & aquatilis & 195 & JP Aomori & Tsugaru & Y. Okuzaki/T. Sota & 2010 & KX380581 \\
\hline maacki & aquatilis & & JP Aomori & & (34) Sota \& Ishikawa & & AY183586 \\
\hline maacki & aquatilis & 75 & JP Yamagata & $\begin{array}{l}\text { Oishida-machi, } \\
\text { Takanosu }\end{array}$ & Y. Nagahata/K. Kubota & 12.06 .2006 & KX380580 \\
\hline maacki & aquatilis & S17 & JP Aomori & Tsugaru & Y. Okuzaki/T. Sota & 2010 & KX380584 \\
\hline maacki & aquatilis & S18 & JP Aomori & Tsugaru & Y. Okuzaki/T. Sota & 2010 & KX380585 \\
\hline maacki & aquatilis & & JP & & (29) Su et al. & & D50358 \\
\hline maacki & maacki & 162 & RU Primorskiy krai & Lazo & D. Vasiliev/A. Matalin & 1989 & KX380588 \\
\hline clatratus & jansoni & 190 & GB Scotland & Isle of Harris & M. Briggs & 16.06 .2012 & KX377440 \\
\hline clatratus & jansoni & 190 & GB Scotland & Isle of Harris & M. Briggs & 16.06 .2012 & KX380589 \\
\hline clatratus & jansoni & 202 & IE Galway & Connemara & G. Kaule & 2007 & KX377444 \\
\hline clatratus & jansoni & 202 & IE Galway & Connemara & G. Kaule & 2007 & KX380582 \\
\hline clatratus & jansoni & 191 & IE Galway & Connemara & G. Kaule & 2007 & KX377442 \\
\hline clatratus & jansoni & 192 & GB Scotland & Dundonnell & G. Pozsgai, D.M. & 03.06 .2012 & KX377442 \\
\hline clatratus & jansoni & $157^{*}$ & IE Galway & $\begin{array}{l}\text { Kilmacduagh, } \\
\text { Turlough }\end{array}$ & R.Anderson & 24.05 .2003 & EU798736.2 \\
\hline clatratus & clatratus & & NL Nord Brabant & De Kempen & (35) Deuve et al. & & JQ646802 \\
\hline clatratus & clatratus & 156 & DE Lower Saxony & Pevestorf & D.M. & 20.01 .2003 & KX377435 \\
\hline clatratus & clatratus & 128 & RU Jakutsk & Nerh-an & Museum Naturk. Berlin & 29.04 .1904 & KX380587 \\
\hline clatratus & clatratus & 138 & RU Jakutsk & Nizhniy Bestyakh & S. Kurbatov/A. Matalin & July 2001 & KX377446 \\
\hline clatratus & clatratus & 138 & RU Jakutsk & Nizhniy Bestyakh & S. Kurbatov/A. Matalin & July 2001 & KX380586 \\
\hline clatratus & auraniensis & 159 & AT Lower Austria & March, Drösing & W. Paill & 27.11 .2002 & KX377437 \\
\hline clatratus & arelatensis & 56 & FR Bouche-du-Rhone & Camargue & D.M. & 23.09 .1980 & KX380590 \\
\hline clatratus & antonelli & 39 & IT Ravenna & Palude di S. Vitale & B. Lassalle & 5.1970 & KX380593 \\
\hline clatratus & antonelli & 40 & IT Ravenna & Palude di S. Vitale & B. Lassalle & 5.1970 & KX380592 \\
\hline clatratus & antonelli & 85 & IT Roma & & $\begin{array}{l}\text { Senckenberg } \\
\text { Museum Frankfurt }\end{array}$ & & KX380591 \\
\hline clatratus & antonelli & 203 & IT Siena & Montepulciano & A.Petrioli/A. Casale & 18.01 .2005 & KX377445 \\
\hline Apotomopterus & iris & & CN Sichuan & Daliangshan & (36) Kim et al. & & AB031504 \\
\hline Apotomopterus & sauteri & & CN Jiangxi & Jinggangshan & (36) Kim et al. & & AB031488 \\
\hline Hygrocarabus & variolosus & * \#157 = & $\begin{aligned} & \text { DE Bavaria } \\
= & \# \mathrm{~N} 241 \text { of EU798736.1 }\end{aligned}$ & Murnauer Moos & (37) Arndt et al. & & $\begin{array}{l}\text { AF231700 } \\
\text { ND5 Wg }\end{array}$ \\
\hline
\end{tabular}

Table 2 Pair-wise distances of mitochondrial ND5 sequences (p \%) of representative specimens of Carabus clatratus, C. porrecticollis and C. maacki from different regions.

\begin{tabular}{|c|c|c|c|c|c|c|c|c|c|c|}
\hline & & & & & & & & & por & llis \\
\hline & & & Far & East & Prim & & & Japan & & \\
\hline & Taxon & Region & 1 & 2 & 3 & 4 & 5 & 6 & 7 & 8 \\
\hline 1 & clatratus & RU Jakutsk 128 & - & 0.6 & 0.6 & 5.2 & 6.0 & 5.6 & 4.8 & 5.2 \\
\hline 2 & clatratus & RU Jakutsk 138 & 0.6 & - & 0.4 & 5.4 & 5.8 & 5.4 & 5.0 & 5.4 \\
\hline 3 & maa. maacki & RU Primorje 162 & 0.6 & 0.4 & - & 5.4 & 6.3 & 5.8 & 5.0 & 5.4 \\
\hline 4 & maa. aquatilis & JP Yamagata 75 & 5.2 & 5.4 & 5.4 & - & 0.8 & 0.4 & 3.3 & 3.3 \\
\hline 5 & maa. aquatilis & JP GenBank & 6.0 & 5.8 & 6.3 & 0.8 & - & 0.4 & 4.2 & 4.2 \\
\hline 6 & maa. aquatilis & JP Aomori S17 & 5.6 & 5.4 & 5.8 & 0.4 & 0.4 & - & 3.7 & 3.7 \\
\hline 7 & porr. kansaiensis & JP Osaka 196 & 4.8 & 5.0 & 5.0 & 3.3 & 4.2 & 3.7 & - & 0.8 \\
\hline 8 & porr. kansaiensis & JP Shiga S19 & 5.2 & 5.4 & 5.4 & 3.3 & 4.2 & 3.7 & 0.8 & - \\
\hline
\end{tabular}




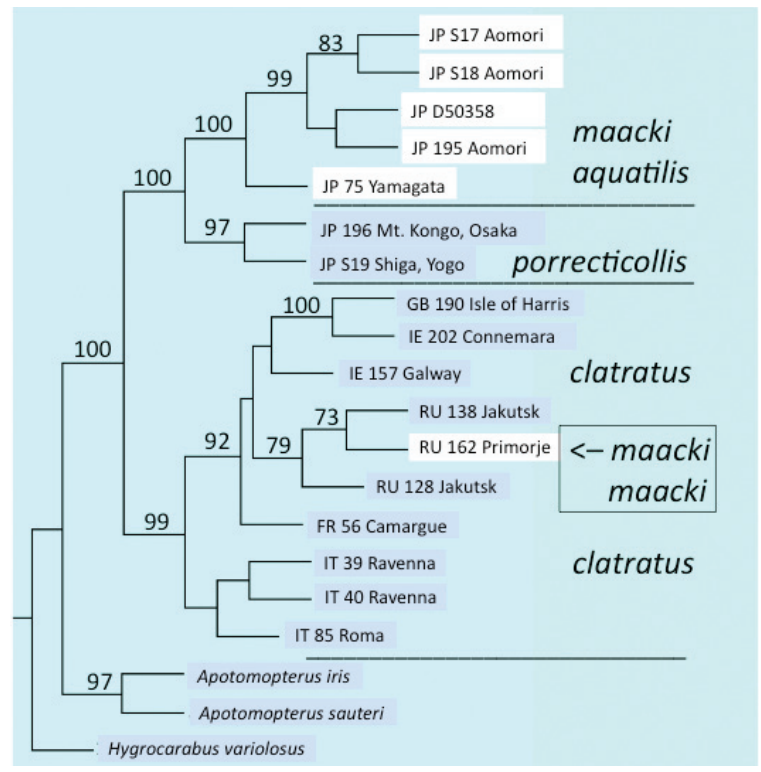

Figure 3 Majority rule consensus tree of ND5 sequences constructed using DNAML.

Bootstrap values $>50 \%$ are shown.

\section{Maximum likelihood tree: ND5}

The Japanese C. maacki aquatilis clustered with $C$. porrecticollis in the maximum likelihood tree of ND5 data, while the C. maacki maacki from the Asian mainland was put into the clatratus group that includes specimens from different regions of Russia and Europe (Fig. 3). This cluster was supported by a high bootstrap value.

\section{Visualisation of sequence differences: ND5}

A lot of positions with exclusive patterns were marked in dark green in Figure 4. The Japanese C. maacki aquatilis shared at least 13 and an additional 7 tentative nucleotide positions with $C$. porrecticollis but none was exclu- sive with C. maacki maacki from the Asian mainland. In addition, at ten positions $C$. maacki aquatilis differed from all the other specimens involved. In contrast, $C$. maacki maacki from the Asian mainland shared the same bases with $C$. clatratus from Europe and the Far East in the aforementioned character blocks.

\section{Nuclear protein-coding gene \\ Maximum likelihood tree: wingless}

The tree constructed by use of a nuclear gene, wingless (Fig. 5), resulted in one well-supported cluster of European C. clatratus and C. maacki aquatilis. Carabus maacki maacki could not be included because fresh material was not available.

\section{Visualisation of sequence differences: wingless}

The data for wingless gene demonstrated in detail, that the pattern of nucleotides was identical for $C$. clatratus and $C$. maacki aquatilis in at least nine exclusive positions. Only one, or at most two, positions displayed a contradictory pattern (highlighted in blue or grey in Table 4).

\section{DISCUSSION}

The introgression hypothesis was supported by the presented data in all three criteria examined:

(i) A specimen from the Asian mainland (C. maacki maacki) displayed a similar pattern to that of $C$. clatratus from various regions in the mitochondrial ND5 sequence but a pattern quite different to the Japanese ones $(C$. maacki aquatilis); (ii) The same result was also apparent in the nucleotide differences as shown by abstract values (\% similarity) and by visualisation of the base patterns. (iii) The nuclear sequence data of wingless displayed minor differences between $C$. clatratus and C. maacki aquatilis from Japan but greater differences with $C$. porrecticollis.

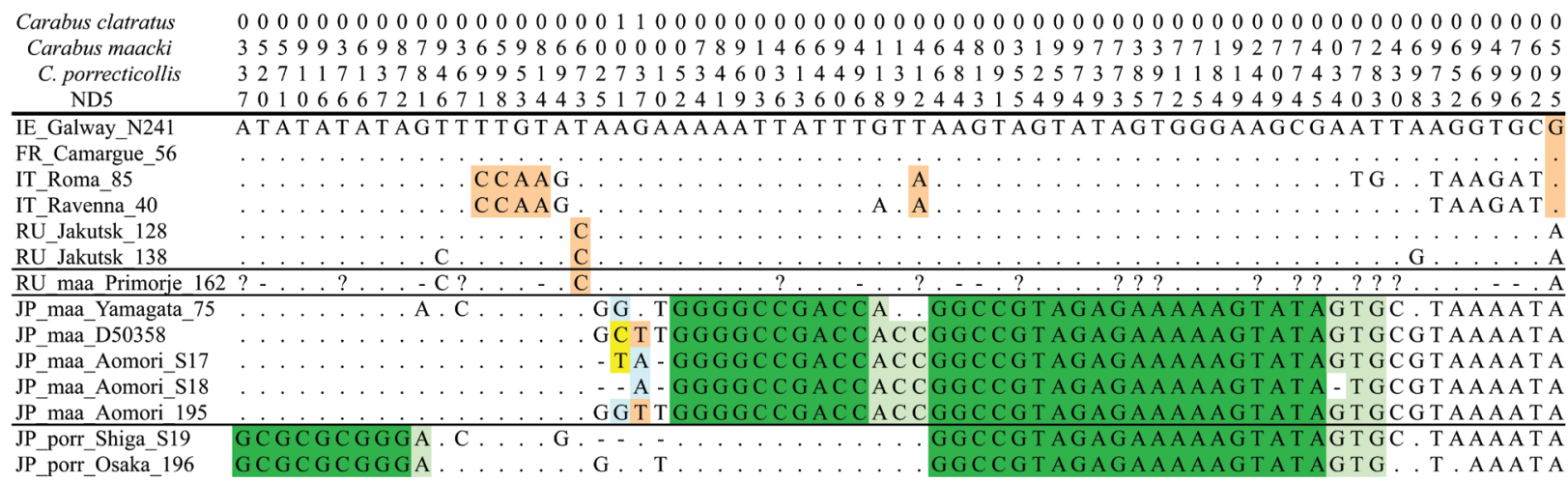

Codon position 3333333313333313333213313233333333333233311313333333323313313323313

exclusive for a group $\quad$ exclusive with exception $\quad$ singleton $\quad+\square$ only here

Figure 4 ND5 base positions of C. clatratus, C. maacki maacki (Primorje), C. m. aquatilis (Japan), and C. porrecticollis that differ in more than one specimen (= singletons omitted). 


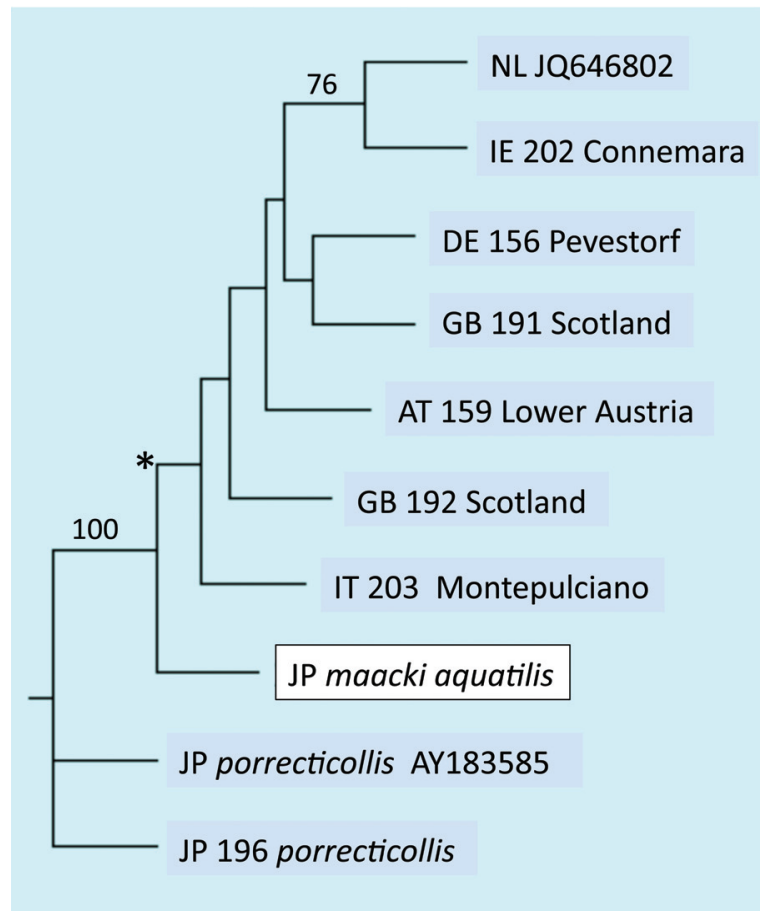

Figure 5 Majority rule consensus tree calculated from sequences of a nuclear gene (wingless) of Carabus clatratus, C. maacki aquatilis and C. porrecticollis.

Bootstrap values $>50$ are shown. The * indicates the branch with C. clatratus from Europe.

These findings are in agreement with the molecular data of Kim et al. (1). They analysed a mitochondrial gene in their study of the $C$. porrecticollis populations of Honshu and included the Japanese $C$. maacki aquatilis as an outgroup. Therefore, they could not detect hybridisation events and they stated for C. porrecticollis (p. 444): ,... there may be several phylogenetic species here instead of just one species with several populations".

Kim et al. (1) found three groups in their thorough investigations of $C$. porrecticollis. Two of these match the described subspecies, the nominate form in the north and C. kanaiensis in central Honshu (Kinki district); the third, from southwestern Honshu (Chugoku district), did not cluster unambiguously and its status remained open. A third subspecies, C. porrecticollis pacificus, was described later from specimens collected from between the Pacific coast and the Fuji Mountain (38).

Considering the morphology, Imura et al. (16) have stated that the molecular differences were small between Carabus maacki aquatilis and C. prorrecticollis, although these taxa were quite different morphologically. Also Kleinfeld (39) drew attention to this remarkable phenomenon.

The present status of Japanese $C$. maacki maacki may be interpreted by an introgressive hybridisation a long time ago for two reasons. The 'porrecticollis' mitochondrion of C. maacki maacki, which differs clearly from that of the $C$. porrecticollis species, and the morphological similarity between $C$. clatratus and both $C$. maacki forms, in contrast to C. porrecticollis.

Both facts indicate that there must have been a lot of backcrosses of the hybrid with $C$. maacki aquatilis despite its partial sympatry with $C$. porrecticollis in the northernmost part of Honshu.

All data conform with the hypothesis of an introgression from $C$. porrecticollis to C. maacki aquatilis. This interpretation conforms with the well-known hybridisation tendency of Carabus species from nature $(2,3)$ and laboratory experiments (5-15).

An alternative interpretation of the data is theoretically conceivable under the assumption of incomplete lineage sorting. A calculation was not done because some sequences don't have the full length, the mitochondrial and the nuclear sequences are partly from different specimens or locations, due to the difficulty in obtaining fresh specimens from many regions, and the missing knowledge of some parameters, such as population size, that are necessary for the procedure. Additionally, the data gave a

\begin{tabular}{|c|c|c|c|c|c|c|c|c|c|c|c|c|c|c|c|c|c|c|c|c|c|c|c|c|c|c|}
\hline Carabus porrecticollis & 0 & 0 & 0 & 0 & 0 & 0 & 0 & 0 & 0 & 0 & 0 & 0 & 0 & 0 & 0 & 0 & 0 & 0 & 0 & 0 & 0 & 0 & 0 & 0 & & D \\
\hline Carabus maacki & 2 & 2 & 2 & 2 & 3 & 3 & 3 & 3 & 3 & 3 & 0 & 2 & 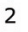 & 3 & 3 & 2 & 3 & 0 & 0 & 0 & 1 & 1 & & 2 & & \\
\hline Carabus clatratus & 8 & 4 & 7 & 9 & 2 & 6 & 3 & 7 & 4 & 0 & 9 & 6 & 7 & 4 & 5 & 5 & 6 & 2 & 7 & 7 & 1 & 0 & 0 & 1 & 2 & 1 \\
\hline Wingless & 9 & 1 & 7 & 2 & 8 & 1 & 1 & 3 & 0 & 4 & 4 & 8 & 8 & 9 & 2 & 9 & 4 & 8 & 6 & 9 & 2 & 9 & 0 & 4 & 4 & 3 \\
\hline $\begin{array}{l}\text { AY183585_C. porrecticollis } \\
\text { 196_C. porrecticollis }\end{array}$ & $\bar{A}$ & $\bar{G}$ & $\bar{A}$ & G & $\bar{T}$ & $\bar{C}$ & C & C & A & $\bar{G}$ & $\bar{C}$ & $\bar{A}$ & T & $\bar{T}$ & $\bar{A}$ & G & C & $\bar{C}$ & A & $\bar{A}$ & C & T & & G & & \\
\hline AY183586_C.maacki aquatilis & G & A & $T$ & $T$ & $\mathrm{C}$ & $\bar{G}$ & G & $T$ & $\bar{G}$ & $\mathrm{C}$ & T & $\bar{G}$ & $\bar{A}$ & C & $\bar{G}$ & $\bar{T}$ & & & . & . & & . & . & . & T & $\bar{A}$ \\
\hline 195_C. maacki aquatilis & G & A & $T$ & $\mathrm{~T}$ & C & G & G & $\mathrm{T}$ & G & C & - & G & A & C & G & $\mathrm{T}$ & & - & - & - & - & - & & . & - & A \\
\hline 138_RU Jakutsk & G & A & T & $\mathrm{T}$ & $\mathrm{C}$ & G & G & $\mathrm{T}$ & G & C & - & . & 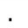 & . & . & 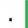 & T & - & - & - & - & - & & . & - & A \\
\hline 202_IE Connemara & G & A & T & $\mathrm{T}$ & C & G & G & $\mathrm{T}$ & G & C & T & . & & . & . & . & $\mathrm{T}$ & A & & & $\mathrm{T}$ & G & C & . & $\mathrm{T}$ & A \\
\hline 191_GB Scotland & G & A & T & T & C & G & G & T & G & C & T & . & & . & . & . & $\mathrm{T}$ & A & G & G & . & G & & . & T & A \\
\hline 190_GB Isle of Harris & G & A & T & $\mathrm{T}$ & C & G & G & $\mathrm{T}$ & G & C & - & . & & . & . & $\mathrm{T}$ & $\mathrm{T}$ & - & - & - & - & - & C & A & - & \\
\hline 192_GB Scotland & G & A & T & $\mathrm{T}$ & $\mathrm{C}$ & G & G & $\mathrm{T}$ & G & $\mathrm{C}$ & $\mathrm{T}$ & . & & . & . & & T & A & G & G & & . & & . & & A \\
\hline 203_IT Montepulciano & . & A & T & $\mathrm{T}$ & C & G & G & $\mathrm{T}$ & G & C & T & . & . & . & . & & T & A & & & T & 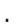 & . & A & & A \\
\hline JQ646802_NL De Kempen & G & A & T & T & C & G & G & $\mathrm{T}$ & G & C & ? & . & & . & . & . & $\mathrm{T}$ & A & G & T & T & G & C & . & T & A \\
\hline 156_DE Pevestorf & G & A & T & $\mathrm{T}$ & C & G & G & $\mathrm{T}$ & G & C & $\mathrm{T}$ & . & & . & . & 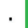 & $\mathrm{T}$ & T & G & G & $\mathrm{T}$ & G & & . & $\mathrm{T}$ & A \\
\hline 159_AT March Drösing & G & A & T & $\mathrm{T}$ & C & & G & $\mathrm{T}$ & G & C & $\mathrm{T}$ & & & . & & & & A & & . & ? & G & & A & $\mathrm{T}$ & \\
\hline
\end{tabular}

Figure 6. Base positions of a nuclear gene (wingless) of C. clatratus, C. maacki aquatilis and C. porrecticollis that differ in more than one specimen (= singletons omitted). 
clear indication, in the nuclear sequences only one or at most two base positions displayed a contradictory pattern (Fig. 6), that may be interpreted by incomplete lineage sorting.

In consequence, the rank of $C$. maacki must be downgraded to subspecies rank; following priority rules, it should be considered that $C$. maacki maacki and $C$. maacki aquatilis are two subspecies of $C$. clatratus: Carabus clatratus maacki from the Asian mainland and C. clatratus aquatilis from Honshu, Japan. To retain two subspecies is in agreement with the differences in ND5 sequences depending on the long separation of Japan from the Asian mainland. The subspecies of $C$. porrecticollis maintain their status.

\section{Acknowledgments}

I would like to thank cordially Jens-Peter Salomon for some sequences (S\#); Michael A. Miller (kmbioservices) for extraction and sequencing; Alexandr Anitchenko, Oleg Berlov, Ortwin Bleich, Yuki Imura \& Kiyoyuki Mizusawa, and Yahiro Katsuro for permission to use their photos; Bernd Jaeger (Museum für Naturkunde Berlin), Klaus-Dieter Klass and Olaf Jaeger (Museum für Tierkunde, Senckenberg Natural History Collections, Dresden), and Damir Kovac (Forschungsinstitut Senckenberg, Frankfurt/M.) for the loan of material; Roy Anderson, Mike Briggs, Achille Casale, Giselher Kaule, Kohei Kubota, Andrey Matalin, Wolfgang Paill, Teiji Sota, for collecting and/or sending material that was used for this study; Gabor Pozsgai for his kind help on a nice Scotland trip and Stephen Venn for his language improvements of the MS.

Last, not least, my sincere thanks are due to three anonymous reviewers. Their comments and suggestions improved the manuscript substantially.

\section{REFERENCES}

1. KIM C-G, TOMINAGA O, SU Z-H, OSAWA S 1999 Origin and Diversification of Euleptocarabus porrecticollis (Coleoptera, Carabidae) in the Japanese Islands Inferred from Mitochondrial ND5 Gene Sequences. Molecular Phylogenetics and Evolution 13 (2): 440444 http://dx.doi.org/10.1006/mpev.1999.0626

2. PUISSÉGUR C 1964 Recherches sur la génétique des Carabes. Vie et Milieu, Suppl. 18: 1-288

3. ALLEMAND R, MALAUSA J-C 1984 Compatibilité génétique et distance phylétique entre les espèces du genre Chrysocarabus Thomson (Col., Carabidae). Ann. Soc. Ent. France (N.S.) 20: 347-363

4. JEANNEL R 1941 Coléoptères Carabiques. Faune de France 39, première partie. Lechevalier, Paris.

5. RASPLUS J-Y, MEUSNIER S, MONDOR G, PIRY S, CORNUET J-M 2000 Microsatellite analysis of genetic population structure in the endangered beetles: Carabus solieri (Carbidae). In: In: Brandmayr P, Lövei G, Zetto-Brandmayr T, Casale A, Vigna Taglianti A (Eds.): Natural History and applied Ecology of Carabid Beetles, p. 11-24 (Proc. 9th Europ. Carab. Meeting, Cosenza 1998) Pensoft Publishers, Sofia-Moscow
6. SOTA T, VOGLER A P 2001 Incongruence of mitochondrial and nuclear gene trees in the Carabid beetles Ohomopterus. Systematic Biology 50 (1),39-59 http://dx.doi.org/10.1080/106351501750107459

7. SOTA T, ISHIKAWA R, UJIIE M, KUSUMOTO F, VOGLER A P 2001 Extensive trans-species mitochondrial polymorphisms in the carabid beetles Carabus subgenus Ohomopterus caused by repeated introgressive hybridization. Molecular Ecology 10: 28332847 http://dx.doi.org/10.1046/j.1365-294X.2001.t01-1-01404.x

8. UJIIE M, KUBOTA K, SOTA T, ISHIKAWA R 2005 Parallel formation of hybrid swarms of ground beetles in the genus Carabus (Coleoptera: Carabidae) in adjacent river basins. Entomological Science 8: 429-437 http://dx.doi.org/10.1111/j.1479-8298.2005.00142.x

9. NAGATA N, KUBOTA K, SOTA T 2007 Phylogeography and Introgressive Hybridization of the Ground Beetle Carabus yamato in Japan Based on Mitochondrial Gene Sequences. Zoological Science 24(5): 465 -474 http://dx.doi.org/10.2108/zsj.24.465

10. TAKAMI Y N, NAGATA M, SASABE M, SOTA T 2007 Asymmetry in reproductive isolation and its effect on directional mitochondrial introgression in the parapatric ground beetles Carabus yamato and C. albrechti. Population Ecology 49: 337-346

11. DÜRING A, BRÜCKNER M, ZIMMERMANN M, BOBENHAUSEN I, EICKE N, MOSSAKOWSKI D 2001 Geographic distribution of two highly different mtDNA haplotypes in Carabus (Chrysocarabus) splendens Olivier. In: Brandmayr P, Lövei G, ZettoBrandmayr T, Casale A, Vigna Taglianti A (Eds.): Natural History and applied Ecology of Carabid Beetles, p. 5-10 (Proc. 9th Europ. Carab. Meeting, Cosenza 1998) Pensoft Publishers, SofiaMoscow.

12. DÜRING A, BRÜCKNER M, MOSSAKOWSKI D 2006 Different Behaviour of Mitochondrial and Nuclear Markers: Introgression and the Evolutionary History of Chrysocarabus. Entomologica Fennica 17: 200-206

13. STREIFF R, VEYRIER R, AUDIOT P, MEUSNIER S, BROUAT C 2005 Introgression in natural populations of bioindicators: a case study of Carabus splendens and Carabus punctatoauratus. Molecular Ecology 14: 3775-3786 http://dx.doi.org/10.1111/j.1365-294X.2005.02714.x

14. ZHANG A B, SOTA T 2007 Nuclear gene sequences resolve species phylogeny and mitochondrial introgression in Leptocarabus beetles showing trans-species polymorphisms. Molecular Phylogenetics and Evolution 45: 534-546

15. ANDUJAR C, GOMEZ-ZURITA J, RASPLUS J-Y, SERRANO J 2012 Molecular systematics and evolution of the subgenus Mesocarabus Thomson, 1875 (Coleoptera: Carabidae: Carabus), based on mitochondrial and nuclear DNA. Zoological Journal of the Linnean Society 166, 787-804 http://dx.doi.org/10.1111/j.1096-3642.2012.00866.x

16. IMURA Y, KIM C-G, SU Z-H, OSAWA S 1998 An attempt at the higher classification of the Carabina (Coleoptera, Carabidae) based on morphology and molecular phylogeny, with special reference to Apotomopterus, Limnocarabus and Euleptocarabus. Elytra 26: $17-35$

17. KIMURA M 1980 A simple method for estimating evolutionary rates of base substituion through comparative studies of nucleotide sequences. Journal of molecular evolution 16: 111-120 http://dx.doi.org/10.1007/BF01731581

18. KAMER N, DORMANN W, MOSSAKOWSKI D 2008 Patterns of molecular variability in Carabid beetles mostly from the Baltic Sea coast. In: Penev L, Erwin T, Assmann T (Eds.): Back to the Roots and Back to the Future. Towards a New Synthesis amongst taxonomical, ecological and biogeographical approaches in carabidology, p. 195-206 Pensoft, Sofia, Moscow.

19. DEUVE T 2004 Illustrated Catalogue of the Genus Carabus of the World (Coleoptera: Carabidae). Pensoft, Sofia, Moscow. 461 pp. 
20. DEUVE T 2012 Une nouvelle classification du genre Carabus L. 1758. Liste Blumenthal 2011-2012. Muséum national d'histoire naturelle, Paris

21. IMURA Y, MIZUSAWA K 2013 The Carabus of Japan. RopponAshi Entomological Books, Tokyo.

22. SCHÜTZE H, KLEINFELD F 2013 Carabusformen ZentralAsiens und Sibiriens. Taxa - Systematik - Bibliographie - Fundorte-Lexikon, 3.ed. Eigenverlag. www.carabus-online.de

23. LÖBL I, SMETANA A 2003 Catalogue of Palaearctic Coleoptera 1: Archostemata - Myxophaga - Adephaga. Brill Academic Publishers.

24. LORENZ W 2014 CarabCat-Checklist (version 1.0). http://carabidfauna.com/checklist.php (Jan.09.2016).

25. OSAWA S, SU Z-H, IMURA Y 2004 Molecular phylogeny and evolution of Carabid Ground beetles. Springer, Tokyo http://dx.doi.org/10.1007/978-4-431-53965-0

26. BLEICH O 2015 European Carabidae. www.eurocarabidae.org

27. ANITCHENKO A 2015 www.carabus.org.

28. BERLOV O 2016 In: Database of Zoological Institute of Russian Academy of Sciences. www.zin.ru

29. SU Z H, OHAMA T, OKADA T S, NAKAMURA K, ISHIKAWA R, OSAWA S 1996. Phylogenetic relationships and evolution of the Japanese Carabinae ground beetles based on mitochondrial ND5 gene sequences. J. Mol. Evol. 42 (2), 124-129

30. DUERING A, BRUECKNER M 2000 The evolutionary history of the tribe Molopini: A first molecular approach. In: Brandmayr P, Lövei G, Zetto-Brandmayr T, Casale A, Vigna Taglianti A (eds) Natural History and applied Ecology of Carabid Beetles. Pensoft, Sofia, Moscow, p. 1-4

31. THOMPSON J D, HIGGINS D G, GIBSON T J 1997. CLUSTAL W: Improving the sensitivity of progressive multiple sequence alignment through sequence weighting, positions-specific gap penalties and weight matrix choice. Nucleic Acids Research 22: 4673 4680 http://dx.doi.org/10.1093/nar/22.22.4673

32. TAMURA K, STECHER G, PETERSON, D FILIPSKI A, KUMAR S 2013 MEGA6: Molecular Evolutionary Genetic Analysis version 6.0 Molecular Biology and Evolution 30: 2725-2729

33. FELSENSTEIN J 2004 PHYLIP (Phylogeny Inference Package) version 3.6. Distributed by the author. Department of Genome Sciences, University of Washington, Seattle.

34. SOTA T, ISHIKAWA R. 2004 Phylogeny and life-history evolution in Carabus subtribe Carabina: Coleoptera, Carabidae) based on sequences of two nuclear genes. Biological Journal of the Linnean Society London 81 (1), 135-149 http://dx.doi.org/10.1111/j.1095-8312.2004.00277.x

35. DEUVE T, CRUAUD A, GNESON G, RASPLUS J-Y 2012 Molecular systematics and volutionary history of the genus Carabus (Col. Carabidae). Molecular Phylogenetics and Evolution 65: 259275 http://dx.doi.org/10.1016/j.ympev.2012.06.015

36. KIM C-G, IMURA Y, OSAWA S 1999 Origin and Evolution of the Apotomopterus ground beetles as deduced from mitochondrial ND5 gene sequences. Elytra 27:643-649

37. ARNDT E, BRUECKNER M, MARCINIAK M, MOSSAKOWSKI D, PRUESER F 2003 Phylogeny. In: Turin H, Penev L, Casale A (eds.) The Genus Carabus L. in Europe. A Synthesis. Pensoft, Sofia, Moscow, 511 pp.

38. IMURA Y, MATSUNAGA M 2011 Discovery of an isolated population of Limnocarabus (Euleptocarabus) porrecticollis (Coleoptera, Carabidae) from the southern foot of Mt. Fuji in Shizuoka Prefecture, Central Japan. Elytra, Tokyo New Series 1 (1): 1-14

39. KLEINFELD F 2002 Zur Stammesgeschichte der Carabidae. Galathea 18 (3): 117-127 